\title{
Application of a Market Competitive Profile in the Process of Making Strategic Decisions
}

\author{
Dinara N. Sabirova ${ }^{1}$ \\ ${ }^{1}$ Kazan (Volga Region) Federal University, Russian Federation \\ Correspondence: Dinara N. Sabirova, Kremliovskaya str. 18, Kazan, 420008, Russian Federation. E-mail: \\ science-kfu@mail.ru
}

Received: June 2, 2014 Accepted: July 9, 2014 Online Published: September 28, 2014

doi:10.5539/ass.v10n20p73 URL: http://dx.doi.org/10.5539/ass.v10n20p73

\begin{abstract}
This study proves the feasibility of such a tool as a market competitive profile for selecting and assessing strategic prospects. Algorithm and methodology of using this tool is presented to determine its advantages and restrictions. We consider the advisability of reworking some elements of the market (competitive) profile to enhance the effectiveness of the companies' strategic choices. Stages of selecting a strategy are detailed using a market competitive profile. The study also deals with one of the most important problems of this method, the translation of quantitative values and qualitative values into a single comparable measurement scale, which results in smoothing the distortions.
\end{abstract}

Keywords: market (competitive) profile, strategic alternatives, strategic choice

\section{Introduction}

Dynamic environmental conditions, the increasing market competition, and the impact of the global economic crisis demand new approaches to the assessment and selection of the key areas of business development (Sarkin, 2014). In this respect, a major problem of management, in our opinion, is the degree of validity in choosing a business strategy. Each company has several alternatives to achieve its goals. However, few organizations focus on the analysis and justification of their forward-looking decisions with due account taken for all factors of their activities. In this context, the need for research and development of the ways to assess the effectiveness of strategic management methods for choosing promising managerial decisions becomes the most urgent task of the today's management.

The purpose of this study is to improve the integrated system of justifying strategic choices of companies with the aid of a market competitive profile.

The study is based on the following scientific concepts: the concept of strategic market management by Aaker (2007), the concept of corporate strategy by Andrews (Andrews, 1987), the innovative development model by Drucker (2001), the five forces model by Porter (Porter, 2006), the balanced scorecard by Kaplan and Norton (2003), the BCG matrix by Mintzberg's school of strategic management (Mintzberg et al., 2001), the strategic management by Thompson and Strickland (2001), and the strategic process model by Macmillan and Tampoe (2000). The issues of strategy effectiveness have also been studied in detail by Russian scientists (Safiullin et al., 2012; Palei, 2014; Melnik, 2013).

In order to explore the issues in focus, the study makes use of the general scientific methods of analysis and synthesis, unity of history and logic, unity of induction and deduction, method of abstraction, and graphical method of representing the results. We also use the methods of situational analysis, strategic matrices, and cluster analysis.

\section{Materials and Methods}

Analysis of the existing approaches to methods and tools for selecting and assessing strategies revealed the following shortcomings of the current tools for the methods used to assess and select a strategy, which are primarily based on quantitative analysis:

1) Underestimation of non-financial indicators;

2) Difficulty in the integrated assessment of implications of strategic decisions; 
3) Calculations based on past performance and studies;

4) Insufficient consideration given to the business value factor.

Applying the system tools with predominantly qualitative indicators for assessing the strategic decisions also has significant limitations associated with the presence of subjectivism, i.e. it does not allow for objective assessment and selection from a number of alternatives. In this case, the effectiveness of this strategic choice also seems questionable.

The shortcomings of the traditionally used strategic choice tools can be remedied either through combining the existing methods or through complementing them with a number of new ones in order to enhance the strategic choice effectiveness. Given the above, we reworked such tool as a market (competitive) profile on the basis of the theoretical analysis, which stands in this study as a synthesis of the methods of the economic indicator systems (balanced scorecard) and the methods of situational analysis (Hamel, 2002). This allows for a combination of qualitative and quantitative methods to determine the competitive ability of a company and identify its "strategic reserves". The objective of this tool is to ensure a balance between market demand and actual capabilities of the company, to obtain necessary information for choosing the best strategic alternatives. The novelty of the said approach to using this tool is shown in Figure 1.
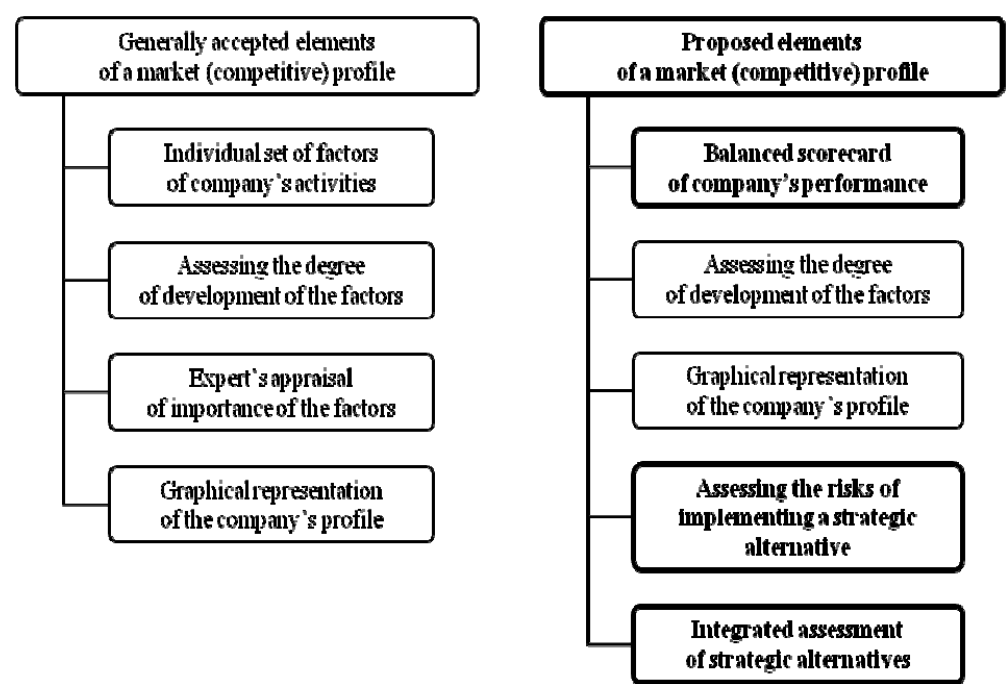

Figure 1. Novelty of using the market (competitive) profile tool

\section{Results}

The use of this tool is based on a theoretical analysis of the shortcomings of existing tools. Let us consider the element-by-element application of the proposed strategic choice concept.

We proceed from the premise of available predetermined and formulated strategic alternatives. In addition to the developed strategic alternatives, we consider a mandatory "status quo" alternative that takes into account the progress of the situation in the case where the company does not implement innovations, maintains the current state of its operations, and does not take active steps to change its current position (Birkinshaw, 2006). It is advisable to assess the key parameters with account taken for both quantitative and qualitative indicators (Dodgson, 2008).

Upon assessing the key parameters of strategic alternatives within the framework of the chosen method, the values of the key parameters are written to the profile table in quantitative and qualitative terms (Bagautdinova, 2014).

It should be noted that one of the most important problems of the proposed method is translating the quantitative values and qualitative values into a single comparable measurement scale, which should result in smoothing the distortions. We propose to split the scope of quantitative values of each attribute into several intervals and assign qualitative characteristic values to each of the intervals. The length of the interval is determined by Eq. 1:

$$
d=\frac{x_{\max }-x_{\min }}{k}
$$


Where:

$x$ are values of an indicator;

$k$ is a predetermined number of the qualitative levels.

The integral value of the market (competitive) profile, based on which the strategy is chosen, is calculated as a sum of the qualitative values of all indicators (Eq. 2):

$$
M C P=\sum m_{i}
$$

Let us consider the application of the interval group for each of the proposed indicators using the example of the chemical industry in the Russian Federation (Panasyuk, 2014). Within the interval group, the number of the qualitative levels $k$ is assumed to be ten (Table 1). This number of the qualitative levels is generally accepted when applying the market (competitive) profile.

Table 1. Proposed interval scale for market (competitive) profile indicators using the chemical industry example

\begin{tabular}{lllll}
\hline No. & Indicator & $\left(x_{\min }\right)$ & $\left(x_{\max }\right)$ & interval, $d($ when $k=10)$ \\
\hline 1 & Market share & $0 \%$ & $35 \%$ & $3.5 \%$ \\
2 & Gain in production & $0 \%$ & $14 \%$ & $1.4 \%$ \\
3 & Return on assets & $0 \%$ & $36 \%$ & $3.6 \%$ \\
4 & Labor productivity growth & $0 \%$ & $10 \%$ & $1 \%$ \\
5 & Cost to revenue rate & $0 \%$ & $14.3 \%$ & $1.4 \%$ \\
6 & Product quality & $0 \%$ & $80 \%$ & $8 \%$ \\
7 & Share of innovative products & $0 \%$ & $18 \%$ & $1.8 \%$ \\
8 & Investment into R\&D & $0 \%$ & $13 \%$ & $1.3 \%$ \\
7 & Growth in accounts receivable turnover & $0 \%$ & $103.4 \%$ & $10.3 \%$ \\
8 & Growth in accounts payable turnover & $0 \%$ & $105.8 \%$ & $10.5 \%$ \\
9 & Quality of remuneration & 0 & 160 & 16 \\
\hline
\end{tabular}

When building the matrix, the columns contain the key indicators of strategy factors, and the rows show the degree of indicator development along a 10-point scale, in accordance with Table 1.

The resulting matrix graphically marks the qualitative value points for each of the indicators. Next, we build a strategic alternative profile, which is a graph that includes the indicators' qualitative value points marked in the matrix.

As an example, we consider the market competitive profile of a Russian company in the chemical industry. The strategic alternatives developed for the company are shown in Table 2.

Table 2. Indicators of the market (competitive) profile for a chemical sector company

\begin{tabular}{|c|c|c|c|c|c|c|c|c|c|c|c|c|}
\hline Strategy & No. & & 1 No. & & 2No. & & 3No. $4 \mathrm{Ve}$ & artical & 1No. 5 & nterec & dNo. 6 & Status \\
\hline Task & $\begin{array}{l}\text { New } r \\
\text { penetrat }\end{array}$ & & $\begin{array}{r}\text { et Increa } \\
\text { marke }\end{array}$ & & Cost re & tion & $\begin{array}{l}\text { Securing } \\
\text { materials }\end{array}$ & raw & $\begin{array}{l}\text { Produc } \\
\text { impro }\end{array}$ & $\begin{array}{l}\text { uality } \\
\text { ent }\end{array}$ & $\begin{array}{l}\text { ty Status } \\
\text { conserva }\end{array}$ & $\begin{array}{l}\text { quo } \\
\text { ration }\end{array}$ \\
\hline $\begin{array}{l}\text { Strategic } \\
\text { alternative }\end{array}$ & $\begin{array}{l}\text { New f } \\
\text { constru }\end{array}$ & & $\begin{array}{l}\text { Upgra } \\
\text { liquid } \\
\text { produc }\end{array}$ & terge & $\begin{array}{l}\text { of Own } \\
\text { ent of heat } \\
\text { reduce }\end{array}$ & $\begin{array}{l}\text { ducti } \\
\text { ower } \\
\text { ts }\end{array}$ & $\begin{array}{l}\text { ion Constructi } \\
\text { toraw mat } \\
\text { plant }\end{array}$ & $\begin{array}{l}\text { ion of } \\
\text { terial }\end{array}$ & $\begin{array}{l}\text { Introd } \\
\text { new ce }\end{array}$ & zer & $\begin{array}{l}\text { of Status } \\
\text { conservo }\end{array}$ & $\begin{array}{l}\text { quo } \\
\text { sation }\end{array}$ \\
\hline $\begin{array}{l}\text { Value } \\
\text { indicators }\end{array}$ & of $_{n}$ & $\mathrm{~m}$ & $\mathrm{n}$ & $\mathrm{m}$ & $\mathrm{n}$ & $\mathrm{m}$ & $\mathrm{n}$ & $\mathrm{m}$ & $\mathrm{n}$ & $\mathrm{m}$ & $\mathrm{n}$ & $\mathrm{m}$ \\
\hline Market share & $25 \%$ & 8 & $19 \%$ & 6 & $18 \%$ & 6 & $22 \%$ & 7 & $18 \%$ & 6 & $16 \%$ & 5 \\
\hline $\begin{array}{l}\text { Gain } \\
\text { production }\end{array}$ & in $_{120 \%}$ & 10 & $0115 \%$ & 10 & $108 \%$ & 6 & $118 \%$ & 10 & $114 \%$ & 10 & $104 \%$ & 3 \\
\hline $\begin{array}{l}\text { Growth } \\
\text { return on asset }\end{array}$ & in $_{\text {ts }} 25 \%$ & 7 & $20 \%$ & 6 & $4 \%$ & 2 & $30 \%$ & 9 & $15 \%$ & 5 & $2 \%$ & 1 \\
\hline
\end{tabular}




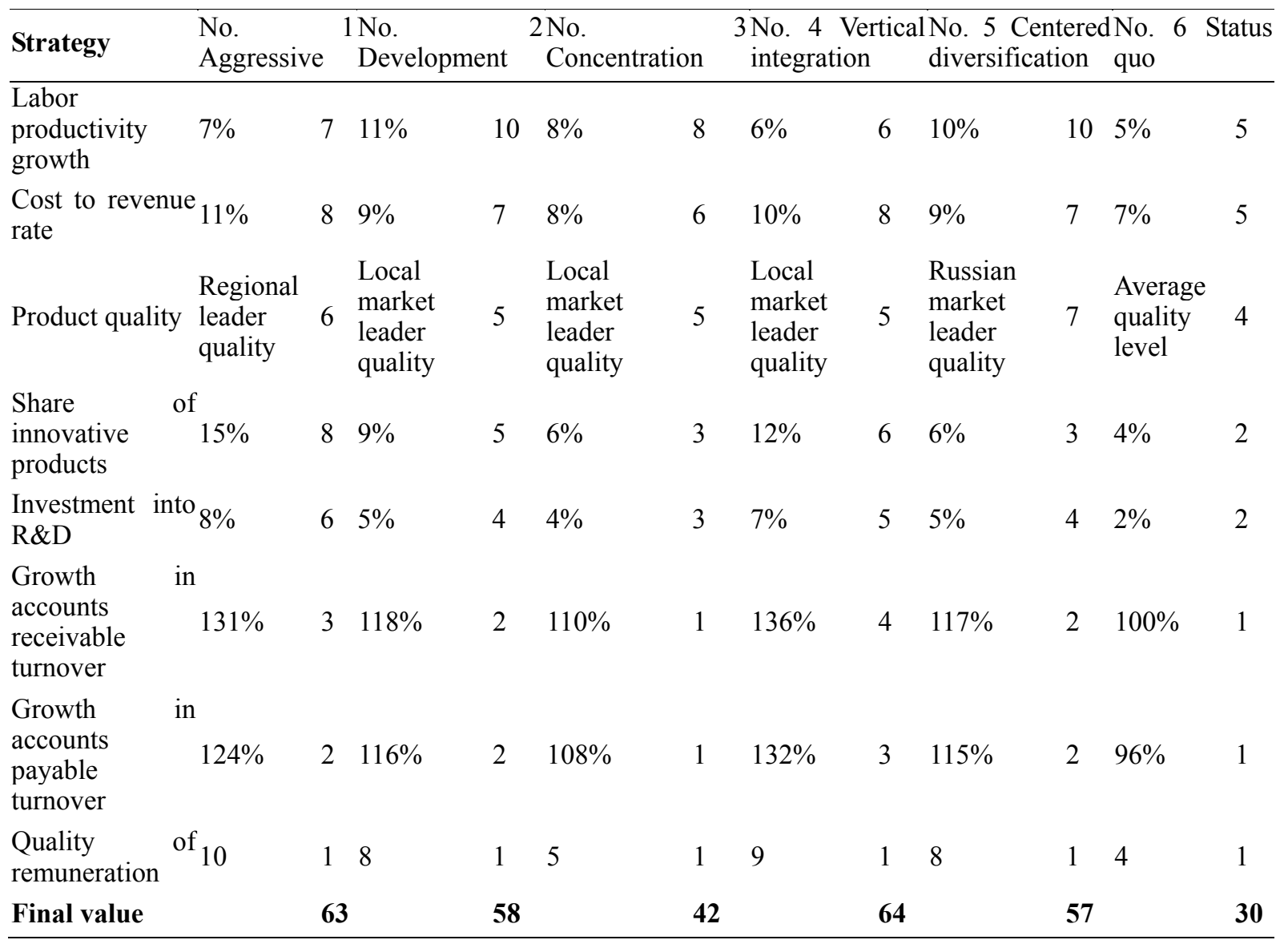

Optimal strategic alternatives will be shifted to the right side of the market (competitive) profile. The main criterion of effectiveness is the largest total amount of the qualitative values in the market (competitive) profile (Eq. 2) of strategic alternatives, which reflects the most efficient use of all factors (Khadiullina, 2014).

Subject to the development of a significant number of strategic alternatives as a further application of a market (competitive) profile, it is possible to use cluster analysis to determine the most appropriate and consistent strategic options. In this case, in order to determine the degree of closeness between the developed strategic alternatives, we suggest using the quality-normalized Manhattan distance (Eq. 3).

$$
W(k)=1-\frac{\sum_{i=1}^{m} \sum_{j=1}^{m} \sum_{k=1}^{m}\left|m_{i k}-m_{j k}\right|}{q *(q-1) * n *(k-1)}
$$

Where:

$q$ is the number of rows in a matrix (number of strategic alternative indicators);

$n$ is the number of columns (number of objects being compared);

$k$ is the number of the specified quality levels (in accordance with the proposed interval scale $k=10$ );

$m i j$ is the qualitative value of the $i$-th indicator for the $j$-th strategic alternative.

Application of the Manhattan distance equation is related to the fact that any metric distance, including the most common Euclidean one, only has the lower (minimum) boundary, zero distance. The quality-normed Manhattan distance has both the lower zero boundary and the upper one, which is equal to unity. The degree of closeness between alternatives is determined using the following gradation as a scale:
$W(k)=1$
absolute closeness
$0.91 \leq W(k)<1$
excellent closeness
$0.81 \leq W(k)<0.91$
good closeness 

$0.71 \leq W(k)<0.81$
satisfactory closeness
$W(k) \leq 0.70$
poor closeness

The graphical representation of the profile is shown in Figure 2.

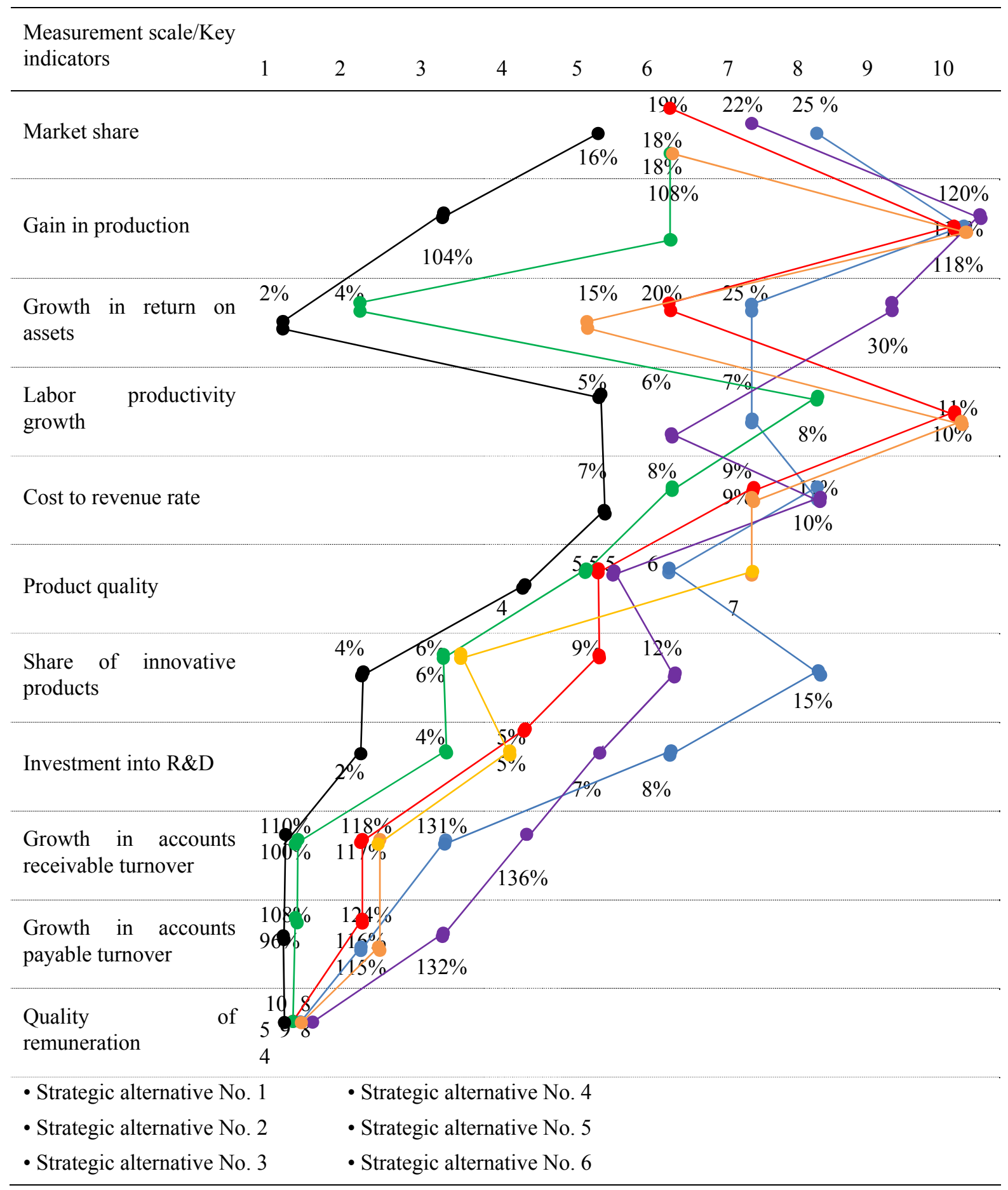

Figure 2. Market competitive profile of a chemical sector company

\section{Discussion}

The proposed concept has the following advantages over the existing methods of assessing and selecting strategies: 
1) Allowance for non-financial indicators in the assessment system;

2) The system of indicators is flexible and can be modified to reflect the specifics of the company and the economic situation;

3) Availability of a balanced, integrated assessment of the effectiveness of the strategic alternatives;

4) Use of both retrospective indicators and planned targets, with due account taken of the current trends in the evolution of internal and external environments;

5) The proposed concept enables the monitoring of strategic actions;

6) The strategy can be translated into specific measurable indicators to provide a feedback for assessing the results and implementing corrective actions.

It is also essential to note the following restrictions on the use of the strategic choice concept in question:

- This system of indicators is not unified. However, the proposed set of factors affecting the formation of strategic alternatives somehow eases this restriction;

- Restricted use of these indicators by public statistics and accounting services;

- Certain amount of subjectivity when assessing and selecting a strategy, since it implies the existence and processing of qualitative indicators.

The proposed methodology of making strategic choices by means of a market competition profile allows for answering the key questions in the process of assessing and selecting a strategy, inasmuch as one often has to contrast largely incomparable alternatives. To that end, the proposed concept provides synergy of the most proven elements of the existing methodological approaches and fills the existing gaps in organizing an effective system of strategic choices for industrial companies.

\section{Conclusion}

The proposed methodology of making strategic choices reflects such basic elements as the organization's strategic goals, strategic alternatives, assessment of the alternatives, and determines the restrictions in the case of eliminating a major element of strategic choice. As a rule, when choosing a strategy within the company's strategic objectives without regard to its analysis and assessment, one takes the risks that the chosen business strategy may turn out to be impracticable. In light of these approaches and in order to eliminate the said shortcomings to assessing the effectiveness and selecting strategies, we proposed and reworked a tool for the strategy assessment and selection, the market (competitive) profile, as a synergy between the methods of economic indicator systems and the methods of situational analysis.

The proposed methodology of making strategic choices allowed us to compare the developed strategic alternatives, assess their effectiveness and to select the most effective strategy with due allowance for the risks in its implementation. The main advantage of this method consists in a more diversified account of the main factors affecting a company. The proposed managerial strategic choice concept brings together a large number of indicators that display the results of the whole system; it draws attention to the gaps between the reference and the actual performance indicators; it allows one to focus on a comparison with the best results rather than on isolated indicators; that is, it provides an opportunity to assess the effectiveness of the company's standing in terms of market and competition, can increase the level of substantiating prospective decisions and their implications, eliminate gaps and underestimations of innovative factors in strategic alternatives, identify strategic levers and breaks, and provide overall assessment of the effectiveness and monitoring of the chosen strategy implementation.

\section{References}

Aaker, D. A. (2007). Strategic market management (7th ed.). St. Petersburg: Piter.

Andrews, K. R. (1987). The concept of corporate strategy. Homewood IL: Dow Jones-Irwin. (Original work published 3th).

Bagautdinova, N., Nayda, A., Hayrullin, B., \& Arzhantseva, N. (2014). Behaviour of Households on Financial Investments Market. Mediterranean Journal of Social Sciences, 5(12), 103-106.

Birkinshaw, J., \& Mol, M. (2006). How Management Innovation Happens. MIT: Sloan Management Review.

Dodgson, M., Gann, D., \& Salter, A. (2008). The Management of Technological Innovation: Strategy and Practice. Oxford: Oxford University Press. (Original work published 2th).

Drucker, P. (2001). Effective Management: Economic Problems and Optimal Solutions. Moscow: Fair-Press. 
Hamel, G., \& Prahalad, C. (2002). Competing for the Future: Creating Tomorrow's Markets. Moscow: ZAO Olimp-Biznes.

Kaplan, R., \& Norton, P. (2003). The Balanced Scorecard: Translating Strategy into Action. Moscow: ZAO Olimp-Biznes.

Khadiullina, G., Bagautdinova, N., Shevko, N., \& Pratchenko, O. (2014). Condition and Development Characteristics of The Russian Market of Information Technilogies. Mediterranean Journal of Social Sciences, 5(12), 21-26.

Macmillan, H., \& Tampoe, M. (2000). Strategic Management: Process, Content and Implementation. New York: Oxford University Press.

Melnik, A., \& Mustafina, O. (2013). The Organization of Russian Power Market in Modern Conditions. Middle-East Journal of Scientific Research, 13, 91-94.

Mintzberg, H., Ahlstrand, B., \& Lampel, K. (2001). Schools of Strategies. St. Petersburg: Piter.

Organization for Economic Cooperation and Development. (n. d.). OECD iLibrary. Retrieved July 24, 2014, from http://www.oecd-ilibrary.org

Palei, T., \& Kornilova, A. (2014). Management of Institutional Factors of Economic Development. Actual economic problems, 3, 38-45.

Panasyuk, M., Pudovik, E., \& Sabirova, M. (2014). Problems of labor market of modern Russia in conditions of stable economic growth. Life Science Journal, 11(6s), 487-489.

Porter, M. (2006). Competitive Strategy: Techniques for Analyzing Industries and Competitors (p. 454). Moscow: Alpina Business Books.

Safiullin, M., Elstin, L., \& Shakirova, A. (2012). Evaluation of Business and Economic Activity as a Short-Term Forecasting Tool. Herald of the Russian Academy of Sciences, 4, 290-294. http://dx.doi.org/10.1134/S101 9331612040053

Sarkin, A., Bagautdinova, B., Khadiullina, G., Averyanov, B., \& Arzhantseva, N. (2014). Development of Paternalistic Strategy of Industrial Growth with Regard to Institutional Traps (Qwerty-Effects). Mediterranean Journal Of Social Sciences, 5(12), 49-54.

Sarkin, A., Bagautdinova, N., Averyanov, B., \& Arzhantseva, N. (2014). The Concept of "New" Paternalism and Its Realization within the State Regulation of Economy. Mediterranean Journal of Social Sciences, 5(12), 27-32.

Sarkin, A., Bagautdinova, N., Averyanov, B., Novenkova, A., \& Arzhantseva, N. (2014). Assessment of Efficiency of Realization of Paternalistic Policy of Industrial Enterprises Development. Mediterranean Journal of Social Sciences, 5(12), 9-14.

Thompson, A., \& Strickland, A. (2001). Strategic Management: Concepts and Cases (9th ed.). Moscow: Infra-M.

\section{Copyrights}

Copyright for this article is retained by the author(s), with first publication rights granted to the journal.

This is an open-access article distributed under the terms and conditions of the Creative Commons Attribution license (http://creativecommons.org/licenses/by/3.0/). 